\title{
Coronavirus: global stocks of protective gear are depleted, with demand at "100 times" normal level, WHO warns
}

\author{
Elisabeth Mahase
}

The BMJ

The demand for personal protective equipment such as masks and respirators is 100 times the normal level, and costs have skyrocketed to around 20 times their usual price, the World Health Organization has reported.

WHO warned of "severe disruption" in the market for personal protective equipment and said that worldwide stocks were "now insufficient" to meet demand. The warning came from WHO's director general, Tedros Adhanom Ghebreyesus, during his opening remarks at a briefing on 2019-nCoV on 7 February.

He said that the situation had been "exacerbated by widespread, inappropriate use of personal protective equipment outside patient care." This has led to "depleted stockpiles and backlogs of four to six months."

Last week The BMJ reported that GPs in Australia were finding it difficult to get the protective masks they needed because of shortages.

Tedros said, "WHO estimates that global frontline health emergency responders will require approximately $7 \%$ to $10 \%$ of market capacity. This percentage may be higher for other critical supplies. Frontline health workers in China require the bulk of personal protective equipment supplies.
"We are appreciative of companies that have taken the decision to only supply masks to medical professionals. There is a limited stock, and we need to make sure we get it to the people who need it most, in the places that need it most. The first priority is health workers. The second priority is those who are sick or caring for someone who is sick."

WHO has advised against stockpiling protective gear in countries and areas where transmission is low.

Tedros called on countries and companies to ensure "fair and rational use of supplies, and the rebalancing of the market." He added, "We all have a part to play in keeping each other safe."

For all The BMSs latest articles on the novel coronavirus outbreak go to bmj.com/ coronavirus.

Mahase E. Novel coronavirus: Australian GPs raise concerns about shortage of face masks. BMJ 2020;368:m477. 10.1136/bmj.m477 32024636

Published by the BMJ Publishing Group Limited. For permission to use (where not already granted under a licence) please go to http://group.bmj.com/group/rights-licensing/ permissions 